\title{
New Books Published by Taylor \& Francis-CRC Press
}

\author{
DOI: $10.1134 / \mathrm{S} 106193481110025 \mathrm{X}$
}

Advances in Chromatography, Grushka, E. and Grinberg, N., Eds., Taylor \& Francis-CRC Press, 2011, vol. $49,461 \mathrm{pp}$.

Handbook of Analysis of Oligonucleotides and Related Products, Bonilla, J.V. and Srivatsa, G.S., Eds., Taylor \& Francis-CRC Press, 2011, 511 pp.

Smith, B.C., Fundamentals of Fourier Transform Infrared Spectroscopy, Taylor \& Francis-CRC Press, 2011, 2nd ed., $211 \mathrm{pp}$.

Ivanova, B., Linearly Polarized IR Spectroscopy: Theory and Applications for Structural Analysis, Taylor \& FrancisCRC Press, 2011, 232 pp.

Hydrophilic Interaction Liquid Chromatography (HILIC) and Advanced Applications, Wang, P.G. and He,W., Eds., Taylor \& Francis-CRC Press, 2011, 610 pp.

Ion Mobility Spectrometry-Mass Spectrometry: Theory and Applications, Wilkins, C.L., Ed., Taylor \& FrancisCRC Press, 2010, 374 pp.

Yan, B. and Zhang, B., Analytical Methods in Combinatorial Chemistry, Taylor \& Francis-CRC Press, 2010, 2nd ed., 238 pp.

Kenkel, J., Basic Chemistry Concepts and Exercises, Taylor \& Francis-CRC Press, 2010, 468 pp.

Electroanalytical Chemistry: A Series of Advances, Bard, A.J. and Zoski, C.G., Eds., Taylor \& Francis-CRC Press, 2010, vol. 23, 328 pp.

Li, P.C.H., Fundamentals of Microfluidics and Lab on a Chip for Biological Analysis and Discovery, Taylor \& FrancisCRC Press, 2010, 418 pp.

Practical Aspects of Trapped Ion Mass Spectrometry, Vol. IV: Theory and Instrumentation, March, R.E. and Todd, J.F.J., Eds., Taylor \& Francis-CRC Press, 2010, $950 \mathrm{pp}$.

Chiral Recognition in the Gas Phase, Zehnacker, A., Ed., Taylor \& Francis-CRC Press, 2010, 247 pp.

Fundamentals and Applications in Aerosol Spectroscopy, Reid, J.P., Ed., Taylor \& Francis-CRC Press, 2010, $535 \mathrm{pp}$.

Patnaik P. Handbook of Environmental Analysis: Chemical Pollutants in Air, Water, Soil, and Solid Wastes, Taylor \& Francis-CRC Press, 2010, 2nd ed., 824 pp.

Kabata-Pendias, A., Trace Elements in Soils and Plants, Taylor \& Francis-CRC Press, 2010, 4th ed., 548 pp.

Manual of Environmental Analysis, Aery, N.C., Ed., Taylor \& Francis-CRC Press, 2010, 300 pp.
Water Quality Concepts, Sampling, and Analyses, Li, Y. and Migliaccio, K., Eds., Taylor \& Francis-CRC Press, 2010, 340 pp.

Practical Aspects of Trapped Ion Mass Spectrometry, Vol. V: Applications of Ion Trapping Devices, March, R.E. and Todd, J.F.J., Eds., Taylor \& Francis-CRC Press, 2009, $566 \mathrm{pp}$.

Using Mass Spectrometry for Drug Metabolism Studies, Korfmacher, W.A., Ed., Taylor \& Francis-CRC Press, 2009, 2nd ed., 451 pp.

Encyclopedia of Chromatography, Cazes, J., Ed., Taylor \& Francis-CRC Press, 2009, 3rd ed. (print version), 2850 pp.

Handbook of Pesticides: Methods of Pesticide Residues Analysis, Nollet, L.M.L. and Rathore, H.S., Eds., Taylor \& Francis-CRC Press, 2009, 628 pp.

Analytical Measurements in Aquatic Environments, Namiesnik, J., Ed., Taylor \& Francis-CRC Press, 2009, 503 pp.

Liu, R.H., Canfield, D.V., and Wang, S.-M., Quantitation and Mass Spectrometric Data of Drugs and Isotopically Labeled Analogs, Taylor \& Francis-CRC Press, 2009, $510 \mathrm{pp}$.

Konieczka, P. and Namiesnik, J., Quality Assurance and Quality Control in the Analytical Chemical Laboratory: A Practical Approach, Taylor \& Francis-CRC Press, 2009, $232 \mathrm{pp}$.

Verbiest, T., Clays, K., and Rodriguez, V., Second-Order Nonlinear Optical Characterization Techniques: An Introduction, Taylor \& Francis-CRC Press, 2009, $192 \mathrm{pp}$.

Biochemical Applications of Nonlinear Optical Spectroscopy, Yakovlev, V., Ed., Taylor \& Francis-CRC Press, 2009, 290 pp.

Perspectives in Materials Characterization, Amarendra, G., Raj, B., and Manghnani, M.H., Eds., Taylor \& Francis-CRC Press, 2009, 192 pp.

Zhang, S., Li, L., and Kumar, A., Materials Characterization Techniques, Taylor \& Francis-CRC Press, 2009, $344 \mathrm{pp}$.

Practical Guidelines for the Analysis of Seawater, Wurl, O., Ed., Taylor \& Francis-CRC Press, 2009, 408 pp.

Houghton, R., Field Confirmation Testing for Suspicious Substances, Taylor \& Francis-CRC Press, 2009, $453 \mathrm{pp}$.

Cecchi, T., Ion-Pair Chromatography and Related Techniques, Taylor \& Francis-CRC Press, 2009, 215 pp.

N. B. Zorov 